\title{
Patterns of investment of the reproductive strategy of two stream-dwelling Characidae
}

\author{
Mazzoni, $R .^{\mathrm{a} *}$ and Iglesias-Rios, . $^{\mathrm{b}}$ \\ aDepartamento de Ecologia, Instituto de Biologia Roberto Alcantara Gomes, \\ Universidade do Estado do Rio de Janeiro - UERJ, \\ Rua São Francisco Xavier 524, Maracanã, CEP 20550-013, Rio de Janeiro, RJ, Brazil

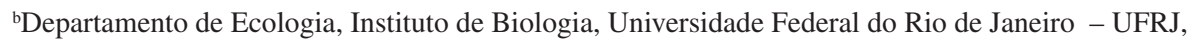 \\ CP 68020, Rio de Janeiro, RJ, CEP 21940-540, Brazil \\ Received April 27, 2005 - Accepted June 5, 2006 - Distributed November 30, 2007 \\ *e-mail: mazzoni@uerj.br
}

(With 3 figures)

\begin{abstract}
The reproductive strategy of two congeneric species (Astyanax janeiroensis - AJ and Astyanax hastatus - AH) was assessed, in order to address the costs imposed by different investment patterns, on four major life history characters: migratory behaviour, breeding time, fecundity and egg size. Altitudinal segregation of young and adult individuals plus data from the literature indicated that $A J$ is a migratory species, whereas $A H$ is non migratory. Breeding season (BS) analysis revealed that $A H$ was reproductively active year-round (12 months), whereas $A J$ breeds during 9 months. Brood costs (Ovarian Investment) were almost the same for both species $(A J-364$ oocytes $/ \mathrm{g}$ and egg volume $=$ $0.52 \mathrm{~mm}^{3} ; A H-702$ oocytes $/ \mathrm{g}$ and egg volume $=0.27 \mathrm{~mm}^{3}$ ). Reproductive costs $(\mathrm{RC})$, considered as product of gamete production (OI) and gamete output (BS), were 1,703.7 for $A J$ and 2,274.0 for $A H$; thus RC is $25 \%$ higher in $A H$. It is concluded that the costs with OI (egg size and egg numbers) are equal for both species but as breeding season is larger for $A H$ the overall strategy is $25 \%$ more expensive in $A H$. Thus, it is hypothesized that this $25 \%$ should be considered as the extra costs that $A J$ uses during migration and is compensated by its shorter breeding time ( 9 months versus 12 months of $A H$ ).
\end{abstract}

Keywords: egg size, fecundity, breeding season, migration, rain forest stream, trade-off.

\section{Padrões de investimento da estratégia reprodutiva de duas espécies de Characidae de riacho}

\begin{abstract}
Resumo
A estratégia reprodutiva de duas espécies congenéricas (Astyanax janeiroensis - AJ e Astyanax hastatus - AH) foi analisada a fim de se determinar os custos energéticos impostos por diferentes padrões de investimento em quatro dos principais caracteres da história de vida de peixes: comportamento migratório, estação reprodutiva, fecundidade e tamanho dos ovócitos. A segregação espacial dos indivíduos jovens e adultos associada a informações da literatura indicaram que $A J$ é uma espécie migratória enquanto $A H$ não migra. A análise sobre a estação reprodutiva (ER) revelou que $A H$ se reproduz ao longo de todo o ciclo anual (12 meses) enquanto $A J$ se reproduz durante 9 meses. Os custos com a desova (Investimento Ovariano - IO) foram similares nas duas espécies (AJ - 364 ovócitos/g e volume dos ovócitos = 0,52 $\mathrm{mm}^{3} ; A H-702$ ovócitos/g e volume dos ovócitos $=0,27 \mathrm{~mm}^{3}$ ). O custo da reprodução (CR), considerado como o produto da produção de gametas (IO) e o tempo de liberação dos gametas (ER), foram 1.703,7 para $A J$ e 2.274,0 para $A H$; assim CR é $25 \%$ superior em $A H$. Concluímos assim, que os custos com IO (tamanho e número de ovócitos) são iguais para as duas espécies, mas como a estação reprodutiva é maior para $A H$, a estratégia como um todo é mais custosa para $A H$. Dessa forma, sugerimos que os $25 \%$ excedentes podem ser considerados como os custos extras que $A J$ necessita para a migração e são compensados pelo menor tempo da estação reprodutiva ( 9 meses em $A J$ versus 12 meses em $A H)$.
\end{abstract}

Palavras-chave: tamanho dos ovos, fecundidade, estação reprodutiva, migração, riacho de floresta pluvial, trade-off. 


\section{Introduction}

Since Williams (1966) introduced the concept of costs of reproduction, some essays were developed and culminated with Stearns (1976), who established the basic tenets for life history theoretical approaches. Therefore, energetic costs of reproduction have been claimed as an essential part of almost every life history theoretical treatment and always discussed in terms of allocation resources. According to Williams (1966), the resources that organisms allocate to reproduction should be partitioned into what they invest at present, which is called reproductive effort and what they save for the future, called residual reproductive value.

Reproductive effort involves energy allocation for, among other, four main life history attributes (migratory behaviour, breeding time, fecundity and egg size) that generate a trade-off between such attributes, during the establishment of the whole strategy (Kinnison et al., 2001). Reznick et al. (2000) state that reproductive effort is part of the whole life history that, in turn, should be thought as being similar to a pie divided into slices, each slice being devoted to a different function. Therefore, increasing the size of a given slice necessarily decreases the size of another slice.

Following this analogy the main goal of the present study was to compare the reproductive strategy of two congeneric species (Astyanax janeiroensis Eigenmann, 1908 and Astyanax hastatus Myers, 1928) in order to address the costs imposed by different investment patterns on four major life history characters: migratory behaviour, breeding time, fecundity and egg size. We formulate a simple equation linking such life history attributes and discuss the trade-offs associated with the maintenance of each life history pattern.

\section{Material and Methods}

\subsection{Study area and sampling procedure}

$A J$ and $A H$ were obtained in Rio Ubatiba $\left(22^{\circ} 60^{\prime} \mathrm{S}\right.$ and $42^{\circ} 48^{\prime}$ W) between July / 1994 and August / 2000. Rio Ubatiba is a $2^{\text {nd }}$ order stream which flows for about $15 \mathrm{~km}$. Seven sites (S1 to S7) were bimonthly sampled by electro fishing (Mazzoni et al., 2000), through the three removal method (Zippin, 1958) and differed mainly by its position in the longitudinal axis being $\mathrm{S} 1$ the one near the headwaters ( 150 a.1.) and S7 ( 5 a.1.) the one near the confluence with Lagoa de Maricá. Despite its small catchment, since 1987, the Ubatiba River has been exploited as a water supplier for Maricá City. The dam is located on its middle reaches, separating the river into two relatively isolated systems. Sites above and below the dam were S1 to S4 and S5 to S7, respectively (Figure 1).

\subsection{Data analysis}

Altitudinal segregation of young and adult individuals is an indicative of differences in the habitat use by different age classes and achieved by up-stream repro-

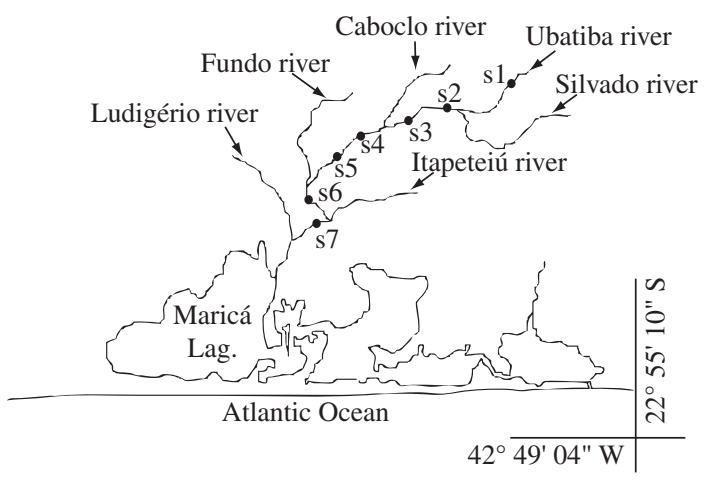

Figure 1. Ubatiba River localization with indication of the seven sampling sites. A black spot, on the upper stretch, indicates the waterfall and the black rectangle, the location of the dam.

ductive migration (= energetic investment) and downstream drift of young and larvae (Mazzoni et al., 2004). This pattern of segregation (migratory behaviour) was used as a first indicative parameter of energetic investment with reproduction and was tested, for $A H$, through young and adult individual quantification in an altitudinal gradient of the Ubatiba river. Migratory behaviour of $A J$ was demonstrated by Mazzoni et al. (2004) with the same methodology.

The extension of Breeding Season (BS), considered as the number of months with breeding individuals, was the second indicative parameter of energetic investment and determined through the temporal occurrence of reproductive females (ripe and spawned ovaries). The third parameter, egg size and fecundity, were obtained from the literature (Mazzoni and Petito, 1999; Mazzoni et al., 2005) and treated as Ovarian Investment $(\mathrm{OI})$, by the following model: $\mathrm{OI}=\mathrm{F} * \mathrm{EV}$; where, $\mathrm{F}=$ fecundity (number of eggs / $\mathrm{g}$ of fish) and $\mathrm{EV}=$ mean volume of ripe eggs. A measurement of the reproductive cost (RC) of each species, that is the breeding season fecundity (sensu Wootton, 1990), was estimated with a simple equation linking OI and BS values: $\mathrm{RC}=\mathrm{BS} * \mathrm{OI}$.

\section{Results}

A. janeiroensis $(A J)$ occurred at the seven studied sites whereas $A$. hastatus $(A H)$ was found from $\mathrm{S} 2$ to $\mathrm{S} 7$, being absent at $\mathrm{S} 1$ that is exactly above a waterfall of about 4 a.l. (Table 1). Spatial segregation of young and adult individuals, as a consequence of reproductive migration, was registered by Mazzoni et al. (2004) for $A J$ (Figure 2a), but no clear segregation was registered for young and adult individuals of $A H$ (Figure $2 \mathrm{~b}$ ).

The extension of breeding season (BS) was 9 months for $A J$ and 12 months for $A H$ (Figure 3). The number of eggs / unit of weight (F) did not vary with fish size for both species. Mean values of $\mathrm{F}$ and volume of ripe 
Table 1. Spatial occurrence of Astyanax janeiroensis and Astyanax hastatus along the seven sampled sites (S1... S7) in the Ubatiba river.

\begin{tabular}{lccccccc}
\hline \multicolumn{1}{c}{ Species } & \multicolumn{8}{c}{ Sites } \\
\cline { 2 - 8 } & S1 & S2 & S3 & S4 & S5 & S6 & S7 \\
\hline Astyanax janeiroensis & $\mathrm{x}$ & $\mathrm{x}$ & $\mathrm{x}$ & $\mathrm{x}$ & $\mathrm{x}$ & $\mathrm{x}$ & $\mathrm{x}$ \\
Astyanax hastatus & & $\mathrm{x}$ & $\mathrm{x}$ & $\mathrm{x}$ & $\mathrm{x}$ & $\mathrm{x}$ & $\mathrm{x}$ \\
\hline
\end{tabular}

(a)

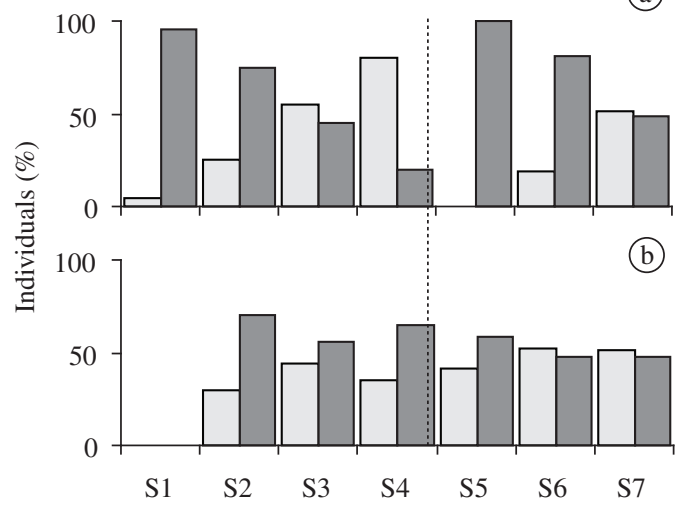

Figure 2. Spatial distribution of young (grey bars) and adult (black bars) individuals of a) Astyanax janeiroensis and b) Astyanax hastatus. Dotted line indicates the dam position.

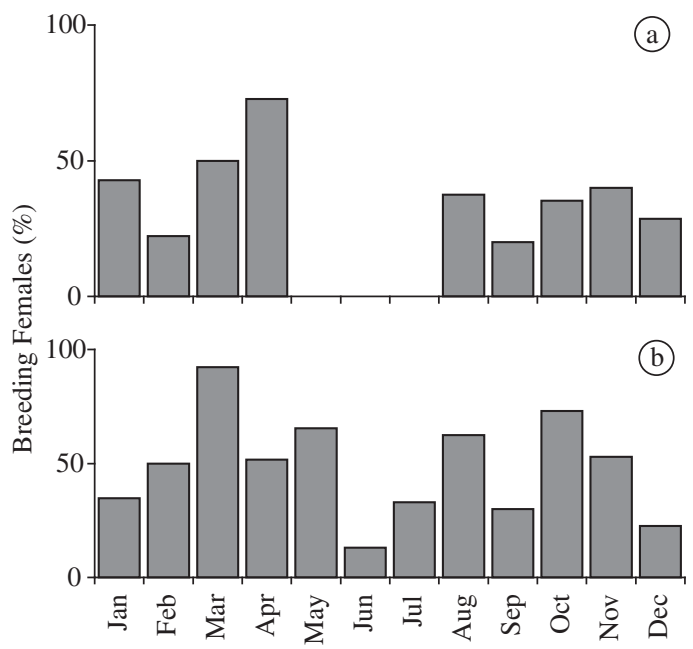

Figure 3. Temporal distribution of breeding females of a) Astyanax janeiroensis and b) Astyanax hastatus.

eggs were $364 \pm 86$ oocytes $/ \mathrm{g}$ and $0.52 \mathrm{~mm}^{3}$ for $A J$ and $702 \pm 125$ oocytes $/ \mathrm{g}$ and $0.27 \mathrm{~mm}^{3}$ for $A H$. Such contrasting values determines OI of 189.3 and 189.5 for $A J$ and $A H$, respectively, and indicate that both species spend a similar amount of energy in gamete production.
Thus, as both species have a similar reproductive strategy when breeding season and oocytes recruitment are considered (Mazzoni and Petito, 1999; Mazzoni et al., 2005) RC, at the population level, considered as a measurement of gamete production (OI) and gamete release (BS), were 1,703.7 for $A J$ and 2,274.0 for $A H$; thus RC is $25 \%$ higher in $\mathrm{AH}$.

\section{Discussion}

Comparison of the breeding season of both species indicates that $A H$ invests a larger amount of time in reproducing. $A H$ produces a large amount of small eggs whereas, $A J$ produces a smaller number of relatively big eggs. Such contrasting strategies determined, at least, no differences of OI of each species (OI = 189.3 in $A J$ and 182.5 in $A H$ ) and suggest that, despite the differences in the allocation strategy, both species spend the same amount of energy when gametic production is considered.

It is well documented that energetic investment with migration can affect the evolution of allocation patterns in closely related species, determining rigorous tradeoffs between egg size and number (Sargent et al., 1987; Healey, 2001; Kinnison et al., 2001) as well as breeding time and migration. A consistent amount of information, concerning breeding season of migrating and nonmigrating fish species from the upper Rio Tocantins, has shown negative correlation between breeding time and migratory behaviour (unpublished data).

The occurrence of $A J$ at $\mathrm{S} 1$ in contrast to the absence of $A H$ plus the spatial segregation of young and adult specimens of $A J$ in contrast to the absence of such pattern among the $A H$ population, indicate the ability of the latter in transposing barriers and corroborates the proposition that, in opposition to $A H, A J$ is a migratory species (Mazzoni et al., 2004). Thus, assuming that reproduction is a driving force for the ascent of adult fishes and that ascending involves a high loss of somatic energy (Dodson, 1997; Leonard and McCormick, 1999) AJ spends more energy than $A H$, when such aspect of reproductive strategy (migration) is considered. In fact, it was estimated that the costs with OI (egg size and egg numbers) are equal for both species but the overall strategy, the above parameter plus breeding time, is $25 \%$ more expensive in $A H$. Thus, it is hypothesized that this $25 \%$ should be considered as the extra costs that $A J$ uses during migration and is compensated by its shorter breeding time (9 months versus 12 months of $A H$ ).

Despite the scarce information about migration of Neotropical fishes, it is well known that it is metabolically expensive, particularly if followed by reproduction (Blem, 1980; Brett, 1995; Sandberg and Moore, 1996). In such cases it is expected that fecundity and eggs size co-evolve in order to enhance reproductive success and compensate energetic output (Leggett and Carscadden, 1978; Snyder and Dingle, 1989). Following this rationale, the patterns of energetic allocation for reproduction of $A J$ and $A H$ are in agreement with most observed mod- 
els for other Osteichthyes species. It is suggested that the reproductive strategy of both species followed important decisions between ovarian investment and migratory behaviour. $A J$ compensates the low $\mathrm{OI}$ with migratory behaviour whereas $A H$ compensates non-migrating behaviour with a high $\mathrm{OI}$.

The reproductive benefits associated with migration are well known and their role has been extensively considered for fish populations from holartic region (Legget, 1985; Roff, 1988; Gross et al., 1988). Nonetheless, very scarce information is available concerning the evolutionary patterns that determine this behaviour among neotropical species and less about the mechanisms that trigger migratory movements. Mazzoni et al. (in press), present the first evidence of migratory behaviour among a Tetragonopteriinae (Characiform) species from a coastal stream from Serra do Mar (Southeast Brazil) and propose that it is an adaptive response to eggs and larval drift.

According to Kinnison et al. (2001), the existence of migratory behaviour within a taxonomic group imposes energetic constraints that contribute to the variation in allocation to other major attributes such as total ovarian investment or parental care. By the same rationale, it is expected that among migratory species the cost of migration could drive initial divergence in reproductive allocation, with implications for long-term patterns. Despite the fact that neither tissue composition nor energy content of $A J$ and $A H$ specimens were measured, before and/or after reproductive events, it is hypothesised that the observed patterns of fish movement, breeding time and egg production, should be explained as an important decision between these attributes of the reproductive strategy. In the case of the studied species, a clear case of trade-off was observed. Differences in ovarian investment, manifested as a decrease in egg size and increase in number within $A H$, and the contrary plus migratory behaviour within $A J$, could be interpreted as a life history strategy that enhances reproductive success of both and preserve their differentiated genotypes. Following these results, it would be convenient to test the hypothesis that despite the adopted strategy, almost all fish species spend the same amount of resources during reproduction.

Acknowledgments - We thank Érica Pellegrini Caramaschi and Javier Lobón-Cerviá for helpful comments on the manuscript; Daiza Lima, Jaqueline Petito, Jean Carlos Miranda, Leandro Damião Soares da Costa, Sérgio Andreas Schubart and many other students for assistance during the fieldwork and Chiara Mazzoni for the English revision. This work was supported by grants from FAPERJ / APQ1 / E-26/171.555-00 and CNPq / APQ-47942601-5.

\section{References}

BLEM, WA., 1980. The energetics of migration, p. 175-213. In GAUTHREAUX-Jr., SA. (ed.), Animal Migration, Orientation and Navigation. Academic Press, Nova York.

BRETT, JR., 1995. Energetics, p. 3-68. In GROOT, C., MARGOLIS L. and CLARKE, WC. (eds.), Physiological
Ecology of Pacific Salmon. University of British Columbia Press, Vancouver.

DODSON, JJ., 1997. Fish migration: an evolutionary perspective, p. 10-36. In GODIN, JJ. (ed.), Behavioural Ecology of Teleost Fishes. Oxford University Press, Oxford.

GROSS, MT., COLEMAN, RC. and McDOWALL, R., 1988. Aquatic productivity and the evolution of diadromous fish migration. Science, vol. 239, no. 4845, p. 1291-1293.

HEALEY, MC., 2001. Patterns of gametic investment by female stream and ocean-type Chinook salmon. J. Fish Biol., vol. 58, no. 6, p. 1545-1556.

KINNISON, MT., UNWIN, MJ., HENDRY AP. and QUINN TP., 2001. Migratory costs and the evolution of egg size and number in introduced and indigenous Salmon populations. Evolution, vol. 55, no. 8, p. 1656-1667.

LEGGETT, WC., 1985. The role of migrations in the life history evolution of fish. Cont. Mar. Sci., vol. 27, p. 227-295.

LEGGETT, WC. and CARSCADDEN, JE., 1978. Latitudinal variation in reproductive characteristics of American shad (Alosa sapidissima): evidence for population specific life history strategies for fish. J. Fish. Res. B. Can., vol. 35, p. 1469-1478.

LEONARD, JBK. and McCORMICK, SD., 1999. Effects of migration distance on whole-body and tissue-specific energy use in American shad (Alosa sapidissima). Can. J. Fish. Aq. Sci., vol. 56, no. 7, p. 1159-1171.

MAZZONI, R. and PETITO, JT., 1999. Reproductive biology of a Tetragonopterinae (Osteichthyes, Characidae) of the Ubatiba fluvial system, Maricá - RJ. Braz. Arch. Biol. Technol., vol. 42, no. 4 , p. $455-461$.

MAZZONI, R., FENERICH-VERANI, N. and CARAMASHI, EP., 2000. Electrofishing as a sampling technique for coastal stream fish populations in the Southeast of Brazil. Revta. Brasil. Biol. vol. 60, no. 2, p. 205-216.

MAZZONI, R., SCHUBART, SA. and IGLESIAS-RIOS, R., 2004. Longitudinal segregations of Astyanax janeiroensis in Rio Ubatiba: a Neotropical stream of south-east Brazil. Ecol. Freshw. Fish, vol. 13, p. 231-234.

MAZZONI, R., MENDONÇA, RS. and CARAMASCHI, EP., 2005. Reproductive biology Astyanax janeiroensis (Osteichthyes, Characiidae) from the Ubatiba River, Maricá RJ. Brazil. Journ. Biol, vol. 65, no. 4, p. 643-649.

REZNICK, D., NUNNEY, L and TESSIER, A., 2000. Big houses, big cars, superfleas and the costs of reproduction. Tree, vol. 15 , no. 10 , p. $421-425$.

ROFF, DA., 1988. The evolution of migration and some life history parameters in marine fishes. Env. Biol. Fish., vol. 22, no. 2 , p. $133-146$.

SANDBERG, R. and MOORE, FR., 1996. Fat stores and arrival on the breeding grounds: reproductive consequences for passerine migrants. Oikos, vol. 77, no. 3, p. 577-581.

SARGENT, RC., TAYLOR, PD. and GROSS, MR., 1987. Parental care and the evolution of egg size in fishes. Am. Nat., vol. 129 , no. 1 , p. 32-46.

SNYDER, RJ. and DINGLE, H., 1989. Adaptive genetically based differences in life history between estuary and freshwater three-spine sticklebacks (Gasterosteus aculeatus L.). Can. J. Zool., vol. 67, p. 2448-2454. 
Reproductive costs of stream-dwelling fishes

STEARNS, SC., 1976. Life-history tactics: a review of ideas. Quat. Rev. Biol., vol. 51, no. 1, p. 3-47.

WILLIAMS, GC., 1966. Natural selection, the cost of reproduction and a refinement of Lack's principle. Am. Nat., vol. 100 , no. 5, p. 687-690.
WOOTTON, RJ., 1990. Ecology of Teleost Fishes. Chapman \& Hall, London. 386p.

ZIPPIN, C., 1958. The removal method of population estimation. J. Wild. Mang., vol. 22, no. 1, p. 82-90. 